\title{
非混合液一液界面における表面張力の測定 Measurement of the Interface Tension of Immiscible Liquids Interface
}

\author{
○正 染矢 聡 (産総研) \\ 正 宗像 鉄雄 (産総研) \\ Satoshi SOMEYA and Tetsuo MUNAKATA, National Institute of Advanced Industrial Science and Technology, 1-2-1 \\ Namiki, Tsukuba, Ibaraki
}

\begin{abstract}
Interface tension and temperature coefficient of its gradient between silicone oil (KF96L-2cSt, 5cSt, KF96-10cSt, 20cSt) and fluorinert (FC-40, 3283) were measured. They are very important property when the flow affected by marangoni effect is investigated in a laboratory. Marangoni force due to the gradient of surface tension often affects a flow in a crystal growth process on the ground. In order to damp marangoni convection, applying a liquid encapsulation system has proposed. However, even with the encapsulant, marangoni convection may be still a big problem on the micro gravity condition.

The interface tension was measured by using a commercial interfacial tensiometer based on the pendant drop method at first. However, its measurement accuracy was not so high for our targets, that is, relatively small interface tension and its temperature dependency. Therefore, the interface tension was also measured with an image processing technique. The standard deviation of each measured value was less than $0.03 \mathrm{mN} / \mathrm{m}$.
\end{abstract}

Key Words: Interface Tension, Pendant Drop, Immiscible Liquid, Temperature

\section{1.はじめに}

自由液面・界面上に温度 (または濃度) 分布が存在する場 合, これらに起因して界面・表面張力分布が生じて, 張力 の弱い側から強い側へ，マランゴニ対流と呼ばれる流れが 生じることがある.マランゴニ対流は微小重力環境などレ 一リ一数の小さい条件下で特に顕在化し，その発生や強さ は表面張力温度係数に強く影響されるマランゴニ数 $(\mathrm{Ma}=$ ot $\Delta \mathrm{T} \mathrm{H} / \mu \kappa .(\mu, v, \kappa, \beta は$ 粘性係数, 動粘性係数, 熱拡 散係数, 熱膨張率. $\Delta \mathrm{T}$ は温度差で $\sigma \mathrm{t}$ は表面張力温度係数の 絶対値.)によって評価される.特に微小重力下では密度差 に起因する浮力対流の代わりにマランゴ二対流が流れを支 配する他, 地上でも融液からの単結晶育成過程などで流れ 場に大きな影響を与える。一方, マランゴ二対流を抑制する 一手段として封止液体を用いる方法が提案され, GaSa, InP などの単結晶製造分野では実用化されている。高品位結晶 や新材料製造などの面で注目されている宇宙環境での結晶 育成においては, 材料 (融液)の飛散を防止する効果も期待 できるためDoi，T.ら (1)が EFZ法を提案するなどしている. しかしながら微小重力環境では浮力の効果がないため, 封 止液体によってある程度は抑制されるものの, 液一液界面 上での温度差に起因したマランゴニ対流が発生する。液一 液界面でのマランゴニ対流についてはシリコンオイルとフ ロリナートを用いて地上でも基礎実験 ${ }^{(2)(3)}$ が行われており， これらの実験では作動液体の表面張力温度係数が非常に重 要なパラメータとなるものの,これらに関する研究 ${ }^{(4)}$ はあ まり多くない.

大坪ら ${ }^{(4)}$ は 3 種類のフロリナート $(\mathrm{FC}-40(2.2 \mathrm{cSt}$ at $\left.\left.25^{\circ} \mathrm{C}\right), \mathrm{FC}-43(2.8 \mathrm{cSt}), \mathrm{FC}-70(14.0 \mathrm{cSt})\right)$ とシリコンオイル (KF96L-2cSt) との界面張力温度係数及びこれらの経時変化 をウィルヘルミ法を利用した計器を用いて測定している。 しかしウィルヘルミ法ではプレートに対する両液体の需れ 性が計測結果に大きく影響するため，フロラードなどを用 いてシリコンオイルに濡れ難くしても計測の信頼性にやや 不安が残る.また物性值計測という面では複数の手法を用 いて同様の計測を行うことが望ましいと考えられる。その ため本研究ではペンダントドロップ法を採用してフロリナ ート (FC-40, FC-3283) とシリコンオイル (KF96L-2cSt, 5cSt, KF96-10cSt，20cSt）との界面張力を計測した.

\section{2. 実験装置}

実験では市販されているペンダントドロップ式の界面張 力計 ((株)協和界面科学, PD-X) と外径 15３2G までの注射 針を採用し，測定用七ルの周囲に恒温水を循環させて温度 を制御した.シリコンオイルとフロリナートとの密度差は $\mathrm{lg} / \mathrm{cm}^{3}$ と大きい上，フロラードなどを利用した場合でも低 粘度のシリコンオイルの注射針(ステンレス製)によく濡れ るため, 鉛直下向きの針を用いて比重の大きなフロリナー トの液滴を保持することは非常に難しい，各実験条件で安

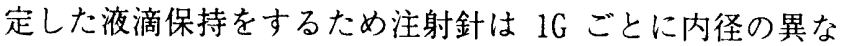
るものを 18 本用意し,これらを鉛直上向きにしてフロリナ ート中にシリコンオイルの液滴を形成することとした。ま た，針に沿った液滴の濡れあがりを抑制するため，注射針 の外側には大坪ら ${ }^{(4)}$ 同様にフッ素系撥水撥油処理剤 ((株)INT スクリーン製 304H) を塗布した。なお，ペンダン トドロップ法の場合, 液滴と注射針との接触角や付着力は 液滴の保持のし易さという点以外では計湘に影響しない.

使用した界面張力計は 0 $50 \mathrm{mN} / \mathrm{m}$ の範囲における測定精 度がカタログ值で $\pm 1 \mathrm{mN} / \mathrm{m}$ とされており, 界面張力が 3 $10 \mathrm{mN} / \mathrm{m}$, その温度係数が $0.03 \sim 0.05 \mathrm{mN} / \mathrm{m} \cdot \mathrm{K}$ と予想される(4) 本研究に利用するには精度が不足している。 そのため各液 体・温度条件で 50 回ずつの測定を行い,これらの平均值と して界面張力を求めた.更にPD-Xで形成した液滴の画像を 直接 PCに取り込み, 画像処理によって独自に界面張力の評 価を行った。

\section{3. 測定結果}

\subsection{PD-Xによる計測結果}

本研究で用いた液体の組み合わせの場合, 形成できる液 滴の幅は $1 \mathrm{~mm}$ 程度であり, $\mathrm{PD}-\mathrm{X}$ 上及びそこから $\mathrm{PC}$ へ出力 される画像 $(640 x 480,8 \mathrm{bit}$ gray)上で 120pixel 程度である. PD-X ではこの画像をモニ夕上で見ながら Fig.1の Al，A2， $\mathrm{P}, \mathrm{B} 1$ ，B2 をマウスで指定する.すなわち 1pixel 単位の大 きさで液滴形状の代表パラメータ(5)を取得する.機器の表 示分解能は $0.1 \mathrm{mN} / \mathrm{m}$ である. 界面張力計 $(\mathrm{PD}-\mathrm{X})$ の校正は付 属の専用シルエット (3 種類)を用いて行い, それぞれ誤差 $\pm 0.1 \mathrm{mN} / \mathrm{m}$ 程度であった. PD-X による計測結果を Fig. 2 に 示した。直線は最小自乗近似で得たものであり, 実線が 
FC-40, 破線が FC-3283 との界面張力を表し, 図の下方ほど 動粘度の小さいシリコンオイルとの界面張力を示している. また, FC-40 と空気との界面張力も計測した結果, $25^{\circ} \mathrm{C} に$ おけるカタログ值 $16 \mathrm{mN} / \mathrm{m}$ に対し, 平均 $15.65 \mathrm{mN}$ 標準偏差は 3\%程度であった.Fig. 2 中の計測結果についても多くの場 合, 標準偏差は計測值の 3\%程度であった. 機器の公称精度 $( \pm 1 \mathrm{mN} / \mathrm{m})$ の 10 倍程度の確度で計測できたことになる。そ こで本計測結果を大坪ら ${ }^{(4)}$ の結果と比較すると, 空気一 FC40, KF96L (2cSt) - FC40 の組み合わせにおける界面張力 温度係数は大坪ら ${ }^{(4)}$ の場合それぞれ 0.078, 0.044, 本研究 (PD-X)ではそれぞれ $0.094,0.042$ であった。後者は比較的 良く一致しているが, 前者は 20\%弱の差がある.また, Fig. 2 の各直線の傾きを調べても特に一定の傾向もみられず係数 値もばらついているため, 係数算出のための測定点が少な い点を考慮しても, 本計測はやや信頼性にかけていると考 えられる。

\section{2 画像処理による算出結果}

液滴の形成・保持などには市販の計測器の利用が適して いるが, 液滴形状の検出を手動かつ 1pixel 単位で行う点が 計測器の信頼性低下につながっていると考えられるため, 観測カメラの出力を直接 PCに取り込んで画像処理によっ て液滴形状を検出する.まず初めに $0.5 \mathrm{~mm}$ 間隔の正方格子 板を注射針と同じ位置に設置・撮影し, 画像上の座標と物 理座標との関係を 3 次多項式に最小自乗近似する。これに よってできるだけ画像の空間的ひずみを取り除く、次に画 像領域全体をスキャンし,Fig. 1 中の A1, A2 や液滴頂点 $(\mathrm{P})$, 注射針の位置の初期值を与え, 液滴の中心軸 (対称軸)を再 帰的手法で算出する.最後にFig. 1 中の 5 点と de, ds を求 め, Ambwani ${ }^{(6)}$ らの式を利用して界面張力を得る.

本手法で FC-40 と空気との界面張力を計測した結果, 平

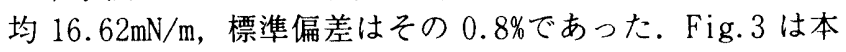
手法による計測結果で, 標準偏差は最大で $0.8 \%$, ほとんど の場合で 0.4\%程度であった。空気一FC40, KF96L (2cSt) FC40 の組み合わせにおける界面張力温度係数はそれぞれ 0.0862, 0.0446 であった. 界面張力温度係数は各フロリナ 一トに対してシリコンオイルの動粘度が大きくなるほど小 さくなり, KF96L (2cSt) と FC-3283 との間の張力温度係数が 最大で 0.0471 であった。

経験式の利用などの他, 本手法の精度に決定的な影響を 与えているのは撮像システムである。これにより現時点で は解析方法によらず，測定精度の向上はあまり期待できな い.すなわち張力・粘度や密度などの関係により大きな液 滴を形成することが困難である一方,バックライト撮影が 可能な精密正方格子の作製が難しいため，十分な精度で校 正しつつ画像解像度を上げることが困難である．そのため 経験式を利用しない手法に発展させつつ, 撮像系も独自の ものを構築する予定である。

\section{4.まとめ}

市販の計測器と画像処理を用いてマランゴニ対流の基礎実 験で重要となる非混合 2 液間の界面張力, 界面張力温度係 数を計測した。

\section{参考文献}

(1) Doi,T. et al., Phys.Fluids A, 5-8(1993), 1914.

(2) Azuma,H. et al., IUTAM Symp. Bremen, 205.

(3) 染矢,マイクログラビティ応用学会誌,19-4(2002), 251

(4) 大坪,マイクログラビティ応用学会誌, 18-1(2001), 29.

(5) Andreas, J.M. et al., J.Phys.Chem., 42(1938), 1001.

(6) Ambwan i,D.S. et al., Surface and Colloid Science,2(1979),93.

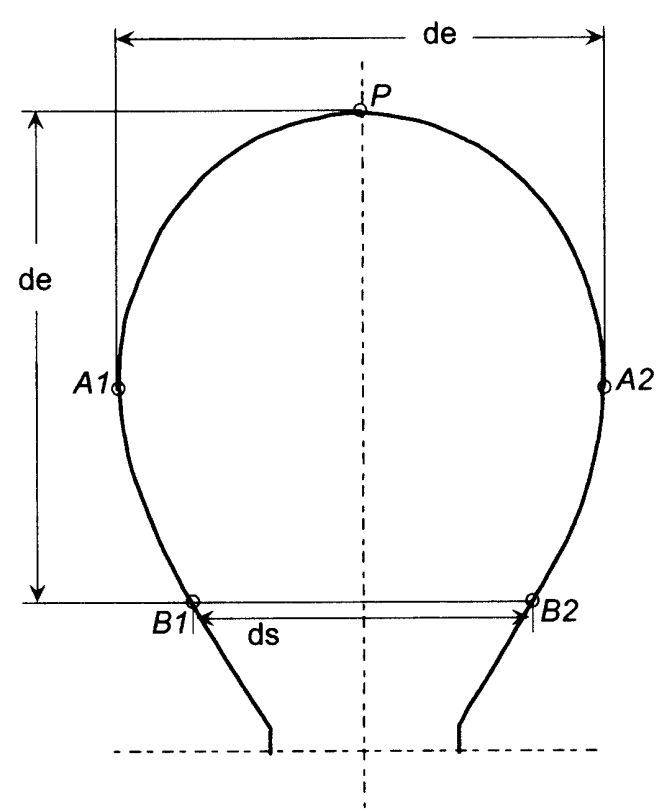

Fig.1 Shape parameter of a pendant-drop

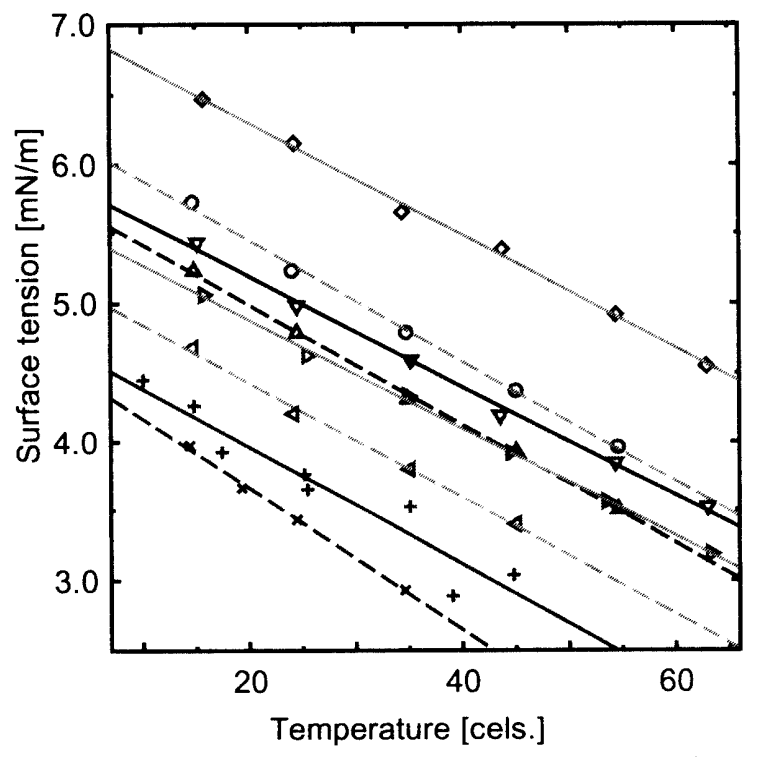

Fig.2 Interface tension measured by $\mathrm{PD}-\mathrm{X}$ tensiometor

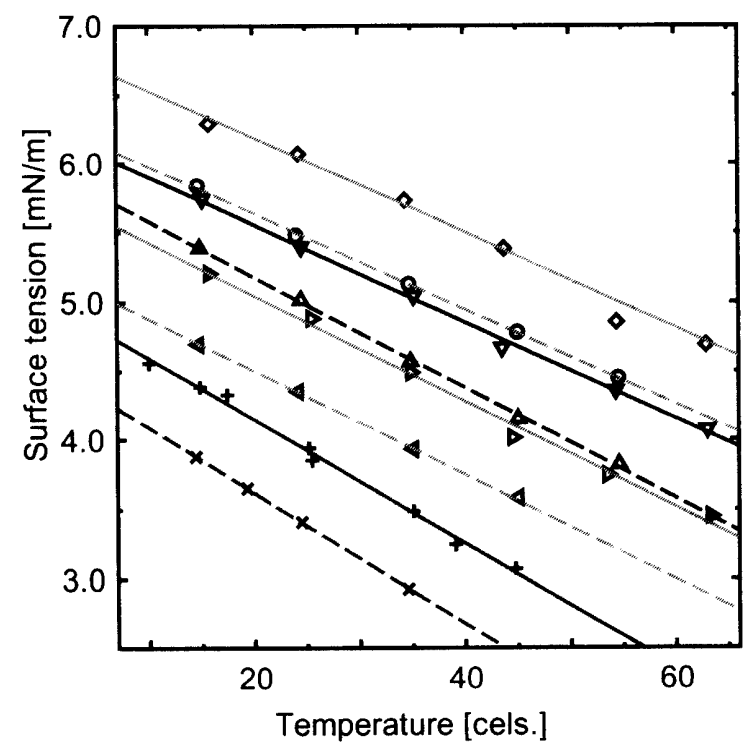

Fig.3 Interface tension estimated with 